\author{
КУЛЬТУРНИЙ КОЛОНІАЛІЗМ ТА ІМПЕРІАЛІЗМ \\ У СОЦІОЛОГІЧНОМУ КОНТЕКСТІ: ЩОДО ПОСТАНОВКИ ПРОБЛЕМИ
}

\title{
CULTURAL COLONIALISM AND IMPERIALISM IN THE SOCIOLOGICAL CONTEXT: TO THE STATEMENT OF THE PROBLEM
}

УдК 316.4

DOI https://doi.org/10.32843/2663-

5208.2020.18.1.3

\section{Гугнін Е.А.}

к.соціол.н., доцент,

перший проректор

Національний університет

«Запорізька політехніка»

\section{Попович В.М.}

д.фрілос.н., доцент,

завідувач кафедри соціальної роботи та психології

Національний університет

«Запорізька політехніка»
У статті побудовано описову характеристику ключових напрямів реалізації культурного колоніалізму й імперіалізму, визначено основні парадигми дослідження культурного колоніалізму й імперіалізму та охарактеризовано освітній, інфрормаційно-технологічний (цифрровий), мистецький, медійно-інфрормаційний матеріально-культурний колоніалізм та імперіалізм.

у результаті проведеного дослідження сформульовано висновок, що культурний колоніалізм та імперіалізм є стратегіями зовнішнього впливу суспільств, які прагнуть здобути культурне, економічне або політичне домінування над іншими суспільствами шляхом насадження їм своїх культурних систем або ї окремих елементів. Наголошено на тому, що культурний колоніалізм та імперіалізм є фуундованими на культурній ідентичності суспільства-гегемона, яка позиціонується як така, що має істотні переваги над суспільством-об'єктом зовнішнього впливу, що є, як правило, об'єктом культурної, політичної та економічної колонізації. Суспільство-гегемон транслює свою ідентичність через культурні коди в різні сегменти культурної системи суспільства-колонії: політику, право, економіку, фрізичну культуру, медіа-комунікації, освіту тощо.

Визначено, що насадження культурної ідентичності суспільства-домінанта може відбуватися паралельно із застосуванням інструментарію військово-політичного й економічного колоніалізму або бути самостійною стратегією. Констатовано, що реакцією суспільств, які стають об'єктами впливу суспільств-колонізаторів i суспільств-імперіалістів, може бути інтерналізація їхніх культурних кодів та ідентичностей або різні за інтенсивністю реакції опору і протидії. При цьому інтенсивність самих контркультурних стратегій суспільств, які стають об'єктами впливу, залежить від розвиненості/нерозвиненості їхної ідентичності й, відповідно, етночентризму та націоналізму як складників ідеологій, фрілософрій, релігій в автентичній культурній системі.

Ключові слова: культурний колоніалізм, культурний імперіалізм, освітній колоніалізм та імперіалізм, інформаційно-технологічний (циорровий) колоніалізм та імперіалізм, мис- тецький колоніалізм та імперіалізм, медійно-інформаційний колоніалізм та імперіалізм, матеріально-культурний колоніалізм та імперіалізм.

The article constructs a descriptive description of the key areas of cultural colonialism and imperialism, identifies the main paradigms for the study of cultural colonialism and imperialism and describes educational, information technology (digital), art, media and information material and cultural colonialism and imperialism.

The study concludes that cultural colonialism and imperialism are strategies of external influence of societies that seek to gain cultural, economic or political dominance over other societies by implanting their cultural systems or their individual elements through

It is emphasized that cultural colonialism and imperialism are based on the cultural identity of the hegemonic society, which is positioned as having significant advantages over the societyobject of external influence, which is usually the object of cultural, political and economic colonization. The hegemonic society translates its identity through cultural codes into different segments of the cultural system of the colony society: politics, law, economics, physical culture, media communications, education, etc.

It is determined that the planting of the cultural identity of the dominant society can take place in parallel with the use of the tools of militarypolitical and economic colonialism or act as an independent strategy. It has been stated that the reaction of societies that become the objects of influence of colonizing societies and imperialist societies may be the internalization of their cultural codes and identities, or different in intensity reactions of resistance and opposition. The intensity of the very countercultural strategies of societies that become objects of influence depends on the development/ underdevelopment of their own identity and, accordingly, ethnocentrism and nationalism as components of ideologies, philosophies, religions in the authentic cultural system.

Key words: cultural colonialism, cultural imperialism, educational colonialism and imperialism, information-technological (digital) colonialism and imperialism, artistic colonialism and imperialism, media-informational colonialism and imperialism and material-cultural imperialism. 
Постановка проблеми. У соціогуманітарних студіях колоніалізм $€$ представленим як історично сформована систему узалежнення одних суспільств іншими. Зазначена система в розвитку охоплює такі історичні періоди:

1. Від великих географічних відкриттів до епохи кризи феодально-монархічного ладу в Європі. Для зазначеного періоду були типовими захоплення територій неосвоєних континентів (Мезоамерика, Африка) і привласнення ресурсів високої капіталізації: золота, срібла, коштовностей, слонової кістки, спецій тощо (іспанська й португальська Конкіста в Америці). У цей період відбувається також торговельна експансія, результатом якої стало встановлення нерівноправних відносин із країнами Сходу (напр., єврофакторії в Азії). Ключовим напрямом колоніальної експансії стає в зазначений період вилучення товарно-сировинних ресурсів із нових континентів до Європи.

2. Промислова революція в Європі та Північній Америці (кінець XVIII - 2 половина XIX століть), у ході якої відбувається переорієнтування колоніальної експансії з вивезення ресурсів із колоній на вивезення готових товарів із метрополій. Отже, якщо на попередньому етапі відбувалося захоплення територій, яке передувало захопленню товарно-сировинних ресурсів, то на цьому етапі стратегія колоніалізму змінилася. Територіальним експансіям тут передує проникнення суспільства-колонізатора на ринки суспільства-колонії.

3. Період імперіалістичної експлуатації колоній (з останньої третини XIX століття), коли за умов усталення вигідних для метрополій товарообмінів відбувається збільшення обсягів вивезення капіталу з метрополій у колонії. Вивезення капіталу, що збільшувалося, мало позитивні наслідки для економічного й політичного зростання суспільств Сходу та Заходу, зокрема для створення армій нового зразка та модернізації виробничих потужностей приватного бізнесу.

У період Другої світової війни й особливо в 2-й половині 40-х - початку 60-х років XX ст. в результаті антиколоніальних рухів розпочався розпад системи колоніалізму. Майже всі колишні колонії здобули незалежність. США, Великобританія, Франція, Нідерланди залишили за собою мізерну порівняно з XX ст. колоніальну периферію, населення якої отримало права, що були аналогічними або близькими до прав жителів метрополій, конституювало самоврядування, отримало фінансово-економічну підтримку від країн-метрополій.

На підставі зазначеного виникли підстави вести мову про зникнення класичного (військово-політичного й економічного) колоніалізму. Однак набуття незалежності, набуття колишніми колоніями обмеженої суб'єктності не гарантувало їм повноцінного суверенітету.
Збереження культурної, політичної й економічної залежності від колишньої метрополії, неперервне втручання метрополій у внутрішні конфлікти в їхніх колишніх колоніях стали прологом культури, політики та економіки неоколоніалізму.

Аналіз останніх досліджень і публікацій. Поняття «культурний імперіалізм» стало частиною наукового дискурсу в XIX ст. й узагальнювало досвід колонізації Індії Британською імперією, маючи початково позитивні конотації. Семантичне поле концепту зазнало негативізації опісля Першої світової війни на тлі ліворадикальної критики імперіалізму.

Одним із систематичних лівацьких критиків культурного імперіалізму став К. Леш [9-10]. Автор в праці «Агонія американського лівацтва» веде мову про культурний імперіалізм США як проникнення американської культури в культурні системи інших держав. Автор наголошує на тому, що культурна експансія, яка подається американською пропагандою як інструмент захисту інтересів демократії, насправді $€$ лише прикриттям для реалізації політичних цілей американської військової машини [10, с. 198-212].

Резонування зазначених ідей у працях із соціології соціального й культурного капіталу в суспільстві та соціології освіти (М. Вебер, П. Бурдьє, Дж.-С. Пассерон, П. Вілліс, Г. Гіро) стало прологом для осмислення освітнього імперіалізму та колоніалізму як тренду системи освіти, що стає інституцією соціального контролю як над своїм, так і над чужими суспільствами, даючи змогу відтворювати й насаджувати культуру, ідеологію та цінності домінуючих соціальних груп суспільства-колонізатора в культурі суспільства-колонії [6, c. 257-291;12, c.619-627; 16, c. 240-244; 17].

М. Фуко, виходячи з теоретичного та історичного аналізу біополітики, уважає: «Заходу найлегше змінити - змінити рівень і форми інвестування в людський капітал. Саме на це в дійсності орієнтуються економічні, а також соціальні, культурні та освітні політики всіх розвинених країн. Точно так само, виходячи з проблеми людського капіталу, можна переосмислити проблеми економіки третього світу. А негнучкість економік третього світу сьогодні потрібно переосмислити не стільки в термінах блокування економічних механізмів, скільки в термінах недостатнього інвестування людського капіталу» [7, с. 82-83].

Кульмінацією розвитку концепції «культурного імперіалізму» як методу передачі ідеології домінуючих держав в інші країни можна назвати дослідження Е. Саїда [13-14]. У ньому, зокрема, автор наголошує на тому, що «сучасний орієнталізм $є$ одним із аспектів імперіалізму й колоніалізму ... і він, на відміну від доколоніальної ерудиції Данте й д’Еребело, утілює 
систематичну дисципліну акумуляції». Зазначений процес для автора «не обмежується інтелектуальними або теоретичними рамками, це неминучим чином призвело орієнталізм до систематичної акумуляції людей і територій». Для дослідника це також означало, що точна реконструкція, наука й навіть уява могли згодом відкрити дорогу арміям, адміністраторам і бюрократії [13, с. 27].

Переосмислення культурного імперіалізму як американської політики, спрямованої на встановлення контролю інших суспільств, розпочалося в 90-х р. в рамках наукових студій соціальної, культурної та ідеологічної «холодної війни». Студії дали змогу здійснити зміщення аналізу «холодної війни» з макроісторії відносин держав та урядів на мікроісторію індивіда як мікропростору культурної агонії [13, с. 27].

Водночас у соціогуманітарних дослідженнях можна простежити створення критичної парадигми розуміння культурного колоніалізму та імперіалізму (Р. Куїсель, Дж. Гієноу-Хехт), прибічники якої вважають, що чутливість до культурної асиміляції з боку суспільства-колонізатора залежить від герметичності ціннісної свідомості культурних еліт [5; 8]. Якщо останні виявлятимуть недостатню толерантність і відповідний етноцентризм, то політика й практика культурного колоніалізму та імперіалізму можуть загальмуватися й навіть викликати реакції у формі контрасиміляційних рухів (або відповідних етноцентричних контркультур).

Постановка завдання. Метою статті $\epsilon$ побудова описової характеристики ключових напрямів реалізації культурного колоніалізму й імперіалізму. Завданнями статті є: 1) визначення основних парадигм дослідження культурного колоніалізму й імперіалізму; 2) побудова описової характеристики освітнього, інформаційно-технологічного (цифрового), мистецького, медійно-інформаційного, матеріальнокультурного колоніалізму й імперіалізму.

Виклад основного матеріалу дослідження. У науковому дискурсі концепти «культурний колоніалізм» і «культурний імперіалізм» можна вважати термінологічними новаціями, попри виражену усталеність поняття «колоніалізм», яким наукова громада послуговується для визначення панування розвинених країн Європи (з кінця XV століття) і США (з XIX століття) над регіонами Азії, Африки, Латинської Америки, Австралії та Океанії (до поч. 60-х р. XX ст.), Японії (1-а пол. XX ст.), Східної Азії та Океанії.

Формування колоніальної периферії Європи й Америки започатковано в епоху Великих географічних відкриттів. Протягом 500 років відбувалося формування метрополій-імперій: Великої Британії, Німеччини, Іспанії, Нідерландів, Португалії, Франції, Бельгії, Данії, Італії, США, Швеції, Японії.
Колоніалізм у його класичному розумінні $€$ фундованим на базуванні військових гарнізонів і колоніальних адміністрацій; установленні торговельних монополій, примусовому вилученні природних ресурсів, позаекономічній експлуатації населення (з використанням інституцій рабства-кріпацтва), тотальному та/ або вибірковому геноциді. Для реалізації колоніальної політики суспільства метрополії створювали спеціалізовані державні органи або приватні корпорації, які опікувалися торгівлею, екстракцією ресурсів, регулюванням демографічних пропорцій суспільства-колонії тощо.

3 розвитком буржуазного суспільства відбувається також еволюція технологій колоніальної експлуатації суспільств периферії. На зміну класичним формам вивезення сировинних ресурсів і живої робочої сили приходить новітня торговельна політика, яка дає метрополії змогу підтримувати режим штучної монокультурності колонії та перетворювати їх на аграрно-сировинні додатки розвиненіших суспільств.

у рамках концепції модернізації колоніалізм, проте, інтерпретується не лише як гальмівне для суспільств-колоній явище, а і як підтримувач їх зростання. Попри культурний, політичний та економічний егоїзм метрополій, у колоніальній периферії відбувалося зростання нової антиколоніальної культури, відбувалося ускладнення соціальної структури, формування альтернативних еліт, безперервно відбувався міжкультурний обмін

Україна, займаючи специфічне геокультурне, геополітичне та геоекономічне становище містка між Сходом і Заходом Європи, із XVII століття й до нашої доби, перетворилася на грально-експериментальний майданчик різноманітних проектерів культурного колоніалізму. Культурний колоніалізм у сучасних умовах можна вважати однією з найдієвіших ідеологій м'якої сили, сутність якої полягає в узалежненні через нав'язування культурної оптики меншовартісності.

Ця оптика меншовартісності є фундованою на засадах побудови такої картини соціального світу й самосприйняття об'єкта зовнішнього впливу, у яких цей об'єкт визнає свою культурну недієздатність, неспроможність формувати автентичні культурні сенси, неможливість обійтися без твердого і надійного опертя в особі гегемона-колонізатора.

У комунікативному аспекті суб'єкти культурного колоніалізму послуговуються расистською риторикою знецінення об'єкта потенційного впливу. Нав'язування йому культурної гегемонії відбувається на основі інфляції власних сенсів і практик, що стає досяжним за рахунок конструювання образу всемогутнього й відповідального за долю слабких світу цього гегемона. Культурна гегемонія колонізатора 
передбачає створення ціннісної системи панування, яка включає міфологічні, релігійні, філософсько-світоглядні, політико-ідеологічні та мистецькі засади.

У міфологічному аспекті культурний імперіалізм фундований на міфі про першородство. Цей міф змістовно збігається з образами та наративами батьківства і старшого братерства, які уможливлюють та обґрунтовують історичну першість і вищість культурного колонізатора над метрополією. При цьому самій метрополії приписується образ дитини, молодшого брата або підлітка, який не розуміє «мудрості життя», «хитрощів, тонкощів і складнощів дійсності» тощо.

У суто історичному сенсі метрополія-«молодший брат», «дитина» або «підліток» презентується в образі архаїчної, відсталої, неспроможної до історичного поступу спільноти. Усі культурні, економічні політичні складники життєустрою цієї спільноти піддаються медійно-пропагандистському знеціненню. Культура метрополії проголошується провінційною та периферійною, політика - архаїчною та корумпованою, недостатньо соціалізованою, економіка - неефективною та відсталою. Простори внутрішньої й зовнішньої культурної експансії відмарковуються як простори вічного минулого, яке потребує осучаснення, модернізації, новації тощо.

Суспільства-культурні колонізатори мають подбати й про власне обожнення у сфері релігійних культів. Для цього зовсім не обов'язково створювати будь-яку неорелігію, оскільки достатньою буває видозміна релігійного позиціонування вже наявної в колонізатора релігії.

Релігія суспільства-колонізатора презентується суспільству-метрополії як розвиненіша, реалістичніша, складніша, просунутіша та гуманніша. Свої амбіції у сфері релігійного узалежнення колонізатор аргументує дикунством, варварством, архаїчністю, демонічністю й жорстокістю релігії суспільства-метрополії.

Така аргументація може використовуватися як самостійно, у пропаганді та міжкультурних комунікаціях, так і як супровід військових інтервенцій і геноцидів. Достатньо звернутися до історичних прецедентів великих географічних відкриттів, які поряд зі звичайним грабунком захоплених територій супроводжувалися також релігійним дискурсом надцінності білої європейської людини.

Дискурс надцінності релігії колонізатора супроводжував також формування Османської імперії в період захоплення територій кавказьких народностей. 3 іншого боку, в історії суспільств $€$ наявними демонстрації релігійної спорідненості, подібності й тотожності релігійної ідентичності в період колонізації. Так, опісля березневих статей 1654 року колонізація українських територій Росією обґрунтовува- лася потребою єднання православних і спільного протистояння «бусурманському ярму».

Колоніальна гегемонія в культурному колоніалізмі й імперіалізмі продовжується в обґрунтуванні нової моделі соціального світопорядку, що дає підстави вести мову про своєрідну філософію культурного колоніалізму й імперіалізму. У цій філософії взасадничується такий тип ідентичності колонізатора, який розбудовує від себе символічний універсум і систему «центр-периферія». При цьому колонії нав'язується периферійна ідентичність у всіх складниках цього світопорядку. Ідеться передусім про неправильну систему цінностей, неправильно обраний шлях історичного розвитку, духовно-культурну нерозвиненість у минулому тощо.

Розбудова системи «центр-периферія» розпочинається з визначення образу Сакральної першореальності й продовжується в розбудові сакрального світопорядку, який має бути визнаний колонією як рятівне коло. Так, британський літератор Р. Кіплінг, який присвячував твори індійському суспільству, міркує про збереження британського колоніального панування в Індії. При цьому критика колоніальної адміністрації та викриття її недоліків, прорахунків не заважають авторові конструювати ідеальний образ британського метрополіала, який був би зануреним у внутрішнє життя індійського суспільства, знав його таємниці, умів злитися з ним, не забуваючи про засадничу місію культурного імперіаліста [2].

Подібний образ вибудовано автором у романі «Кім», сюжетна лінія якого полягає в перебуванні «ідеального колонізатора» в штучно створеному середовищі Британської Індії, яка нібито виключала реальний конфлікт між колонізаторами і колонізованими. Однією з умов збереження британського культурного панування над Індією автор уважав непорушність культурного життєустрою індусів, що також відображало філософію колонізаторів в аспекті розуміння простору колонії як периферійного, а самого населення - як інфантильного, такого, що не є спроможним осягнути духовні переваги ліберальної цивілізації [2].

Колоніальна риторика захисту традиціоналістського життєустрою колонії у філософії колонізатора може супроводжуватися зверхньо-критичним ставленням до автохтонних інтелектуальних еліт при ігноруванні їхніх потенційних здібностей, приниженні, реалістичній оцінці конкурентоспроможності, скепсису щодо освоєння культури суспільства-колонізатора, маргіналізації та периферизації образу колонії тощо.

3 іншого боку, для колонізованих суспільств визнання своєї соціально-історичної та культурної меншовартісності буває комплементарним щодо подібної метрополіальної зверхно- 
сті. Ідеться про відповідні дискурси запізнілих і пригноблених спільнот, їхню культурну маргінальність, репресовану ідентичність, ірраціонально-зрозумілу відсталість тощо.

Ідеологія культурного колоніалізму й імперіалізму змістовно збігається зі створенням і підтриманням культурних асиметрій між різними суспільствами, що відображається в сучасних умовах на розвитку постінформаційної культури, соціальних інституцій і цифрово-зумовлених соціальних ієрархій. Культурний колоніалізм та імперіалізм у соціальних практиках $є$ сукупністю технологій просування та нав'язування культури, культури суспільства-домінанта суспільству-субмісиву.

Відносини домінантності-субмісивності щодо культур і суспільств мають розглядатися в аспекті асиметричного культурного обміну, за умов якого суспільство-метрополія культурно асимілює автентичну культуру суспільства-колонії, що означає для останнього втрату культурного суверенітету, а разом із ним зрілих форм інституційної та соціально-групової спільнотності. Ідеться про руйнацію базових для розвиненого суспільства інституцій: медицини, освіти, культури, ідеологічного апарату тощо, що супроводжується зникненням відповідних соціальних груп і прошарків населення, переважно інтелектуального класу.

Змістом культурного колоніалізму й імперіалізму можна вважати спеціально створені культуро-продукуючими або владно-централізуючими інституціями тих чи інших суспільств стратегії інтервенцій у культуру інших суспільств, етносоціальних спільнот, результатом якої стає створення чужорідної щодо цієї спільноти сфери ціннісної свідомості, соціальних інститутів, статусно-рольових ієрархій, традицій, норм, переконань тощо.

Розгортання стратегії культурного колоніалізму й імперіалізму може відбуватися у відкритих і прихованих формах. За відкритої стратегії між суспільством-метрополією та колонією виникає міжкультурний конфлікт, спричинений відмінностями в ідентичностях суспільств-конфліктерів.

Результатом міжкультурного конфлікту може бути повна/часткова руйнація культурної та/або соціальної системи, що дає змогу в подальшому суспільству-колонізатору нарощувати та закріплювати свій геополітичний, геоекономічний і геокультурний вплив щодо суспільства-колонії. У більшості випадків метою інтервенцій у міжкультурних конфліктах стає відчуження суспільства від культури з наслідками руйнації його культурної ідентичності й подальшим зниженням якості соціальних зв'язків.

За прихованої форми культурно-колоніальної та культурно-імперіалістичної стратегії суспільство-колонізатор застосовує техноло- гії м'якої сили, поняття якої стало вжитковим для дискурсу завдяки Р. Наю. Автор вирізняв у м'якій силі три засадні напрями: 1) культуру; 2) політичну ідеологію; 3) зовнішню політику [3].

Серед типів культурного колоніалізму й імперіалізму варто виділити освітній, інформаційно-технологічний (цифровий), мистецький, медійно-інформаційний, матеріально-культурний колоніалізм та імперіалізм.

Освітній колоніалізм та імперіалізм передбачає насадження культурної ідентичності суспільства-колонізатора засобами освітньої системи та її інституціями: культурно-просвітницькими організаціями, школами, університетами тощо. При цьому йдеться як про просування іншо-етнічних та іншо-культурних закладів освіти в просторі суспільства-колонії, так і про різноманітні програми міжкультурного обміну, які дають змогу формувати кадри з культурною ідентичністю суспільства-колонізатора з людського капіталу суспільства-колонії. Освітній колоніалізм та імперіалізм можуть включати також створення бібліотек, освітніх фондів, надання експертно-консультаційної допомоги суспільствам-акцепторам, упровадження програм навчального обміну тощо $[4$, c. $487-510 ; 15]$.

Інформаційно-технічний (цифровий) колоніалізм та імперіалізм у сучасних умовах співпадають із домінуванням того чи іншого суспільства у сфері виробництва та просування інформаційно-комунікаційних технологій і різноманітних цифрових сервісів, як-от: цифрових фінансів, соціальних мереж, великих даних [1, с. 5-29].

Проекти фінансової цифровізації мають банківське авторство й упровадження. 3 іншого боку, цифрові проекти онлайн-платежів, мобільнихгрошей і цифрової валюти від початку лобіювалися промисловими та інтернет-кампаніями. Самі новації створено в суспільствах із нерозвиненим банківським сектором для компенсування його недоліків. Нині можливості зазначених електронних інструментів використовуються повсюдно [1, с. 5-29].

Захищені онлайнові платежі створюють основи для електронної торгівлі. Електронні переказизнижуютьвитратинапереказикоштів. Взаємне кредитування створює можливості для розширення доступу фінансових коштів для підприємців-початківців. Уряди можуть здійснювати платежі й надавати соціальну допомогу з меншими витратами, знижуючи ризики шахрайства й відтоку фінансів. Разом із тим за відсутності синхронних змін в електронізації фінансів і розвитку регуляторних інструментів зазначені новації створюють нові ризики для стабільності фінансової системи.

Соціальні мережі $€$ засобом соціальних комунікацій, і цифрові технології прискорили процес їх формування. Приблизно 20\% меш- 
канців планети є учасниками однієї або декількох соціальних мереж. Соціальні мережі сприяють вигідній з економічного погляду взаємодії, переорієнтовують поведінку користувачів у векторах розвитку, стають базою для збору й поширення інформації при стихійних лихах і в надзвичайних ситуаціях, а також сприяють залученню учасників до політичного життя й соціальних трансформацій. Соціальні мережі відіграли важливу роль у подіях недавнього минулого («Арабська весна», рух «Захопи Уолл-Стріт»), що дає підстави вважати їх інструментами поширення ідей демократії, хоча їх реальний вплив іноді оцінюється доволі скептично [1, с. 5-29].

Питання про можливу роль соціальних мереж у реалізації зовнішнього впливу потребує їх подальшого вивчення. Як джерело інноваційних ідей соціальні мережі також залишаються каналом поширення пліток, наклепів, недостовірної інформації, домагань, знущань і злочинів. Один із важливих висновків полягає в тому, що використання соціальних мереж як інструментів зовнішнього впливу значною мірою залежить від типу суспільства.

Своюрольтутвідіграютьвідмінностівдоступності технологій, рівневі освіти й соціально-політичній ситуації загалом. Так, наприклад, в автократичних суспільствах люди виявляють менше прагнення поширювати інформацію (наприклад, через ретвіти). У демократичних суспільствах, навпаки, є поширеними практики необмеженого обміну особистою інформацією, що дає додаткові можливості її використання акторами зовнішнього впливу.

Під час дослідження великих даних і відкритих даних у контексті такого предмета дослідження, як зовнішній вплив, у фокусі уваги опиняються дві взаємопов'язані новації. Великі дані відрізняються величезними обсягами і швидкістю передачі й надходять з незліченної кількості джерел - від супутників до сенсорів і від хмар до масових скупчень народу [1, с. 5-29].

Аналітика великих даних застосовується задля вдосконалення планування транспортних потоків, оцінювання укрупнених макроекономічних показників (відоме також як «короткострокове прогнозування»), відстеження ходу поширення епідемій, удосконалення оцінки позичальників і підбору роботи.

Відкриті дані перебувають у вільному й безперешкодному доступі, $є$ дигітальними й доступними для використання без будь-яких обмежень. Найважливішим джерелом відкритих даних є або може бути уряд.

Численні оцінки потенційного економічного значення великих даних і відкритих даних коливаються в межах від сотень мільярдів до трильйона доларів на рік. Однак стійкі, ефективні, укрупнені приклади використання великих даних і відкритих даних у країнах, що розвиваються, зустрічаються відносно рідко, більша частина великих даних перебуває у власності приватних структур - великих компаній електрозв'язку та інтернет-компаній, які не поспішають ділитися ними з побоювання порушити недоторканність особистого життя клієнтів або підірвати конкурентоспроможність компанії [1, с. 5-29].

Розуміючи маніпулятивні можливості послуговування великими даними, державні відомства також не прагнуть ділитися даними, навіть у тих випадках, коли це може забезпечити істотні соціальні зрушення. Так, наприклад, серед країн, які брали участь в опитуванні «Барометр відкритих даних», третина країн із високим рівнем доходу і 85 відсотків країн, що розвиваються, нічого або майже нічого не зробили для того, щоб відкрити картографічні дані. Серед причин цього - зовнішньополітичні та військові перестороги, які на поверхні озвучуються як «відсутність технічних навичок, брак коштів і небажання виносити дані на перевірку».

Цілком самостійним напрямом культурного колоніалізму $є$ мистецький колоніалізм. Він передбачає насадження, популяризацію іншокультурної ідентичності засобами художньої літератури, кіно, музики, образотворчого мистецтва, театру, скульптури тощо.

Медійний (комунікаційний), або електронний колоніалізм та імперіалізм змістовно включає: а) відносини залежності від імпорту інформаційно-комунікаційних технологій (включаючи програмне забезпечення, людський капітал, інформаційні протоколи тощо), що дає змогу суспільству-експортеру інфільтрувати норми, цінності та експектації своєї культурної системи, що може мати наслідком зміну культурної системи суспільства-імпортера й запуск у ньому відповідних соціальних трансформацій; б) контроль над комунікаціями одного суспільства над іншим 3 наслідками підпорядкування пануванню цього суспільства з деконструктивними наслідками для автохтонної культурної системи суспільства-об'єкта панування; в) «стратегія здешевлення медіапродукції спрямована на придушення медіаіндустрій у країнах третього світу за рахунок диспаритетної цінової політики, яка робить функціонування медіаіндустрій у зазначених країнах економічно невигідним і призводить у результаті цього до домінування медіа-лідера продажів у їхньому культурному просторі» [11, с. 74].

Матеріально-культурний колоніалізм та імперіалізм є стратегією насадження культурної ідентичності через різні сегменти фізичної культури, як-от: культури формування тілесності, культури харчування, культури одягу, культури інтер'єризації житла, культури 
дизайну, культури автовиробництва тощо. Так, добре відомим у контексті пострадянського досвіду $є$ американський культурний колоніалізм у сфері культури одягу та культури харчування (предмети одягу 3 котону, перші Мак-Дональдси, нині - американські проекти спортивних комплексів, системи здорового харчування тощо).

Висновки 3 проведеного дослідження. Отже, культурний колоніалізм та імперіалізм є стратегіями зовнішнього впливу суспільств, які прагнуть здобути культурне, економічне або політичне домінування над іншими суспільствами шляхом насадження їм своїх культурних систем або їх окремих елементів.

Культурний колоніалізм та імперіалізм $€$ фундованими на культурній ідентичності суспільства-гегемона, яка позиціонується як така, що має істотні переваги над суспільством-об'єктом зовнішнього впливу, що $€$, як правило, об'єктом культурної, політичної та економічної колонізації. Суспільство-гегемон транслює свою ідентичність через культурні коди в різні сегменти культурної системи суспільства-колонії: політику, право, економіку, фізичну культуру, медіа-комунікації, освіту тощо.

Насадження культурної ідентичності суспільства-домінанта може відбуватися паралельно із застосуванням інструментарію військово-політичного й економічного колоніалізму або бути самостійною стратегією. Реакцією суспільств, які стають об'єктами впливу суспільств-колонізаторів і суспільств-імперіалістів, може бути інтерналізація їхніх культурних кодів та ідентичностей або різні за інтенсивністю реакції опору і протидії. При цьому інтенсивність самих контркультурних стратегій суспільств, які стають об'єктами впливу, залежить від розвиненості/нерозвиненості їхньої ідентичності й, відповідно, етноцентризму та націоналізму як складників ідеологій, філософій, релігій в автентичній культурній системі.

\section{ЛIТЕРАТУРА:}

1. Всемирный банк. 2016 год. Доклад о мировом развитии 2016 «Цифровые дивиденды». Обзор. Всемирный банк, Вашингтон, округ Колумбия. Лицензия: Creative Commons Attribution CC BY 3.0 IGO.

2. Кіплінґ Р. Кім / пер. 3 англ. Ю. Джугастрянська, за ред. В. Чернишенка. Тернопіль : НК-Богдан. 2017. 256 c.

3. Най Дж. «Мягкая сила» и американо-европейские отношения. Свободная мысль - XXI. 2004. № 10. URL: http://smartpowerjournal.ru/soft-power/.

4. Bourdieu P. Cultural Reproduction and Social Reproduction. Karabel J., Halsey A. Power and Ideology in Education. New York, 1977. P. 487-510.

5. Gienow-Hecht J. Transmission Impossible: American Journalism as Cultural Diplomacy in Post-War Germany, 1945-55. Baton Rouge, 1990.

6 . Giroux H. Theories of Reproduction and Resistance the New Sociology of Education. Harvard Educational Review. 1983. Vol. 53. № 3. P. 257-291.

7. Foucault M. «Truth and Power» in Faubion, James D. (ed.) Essential Works of Foucault. Volume 3. Power New York: The New Press, 1979.

8. Kuisel R. Seducing the French: The Dilemma of Americanization. Berkeley, Univ. Press, 1993.

9. Lasch Ch. The Agony of American Left. New York, 1969.

10. Lasch Ch. The Cultural Cold War. The Nation. 1967. 11 September. P. 198-212.

11. Lee, Siu-Nam Lee (1988). «Communication imperialism and dependency: A conceptual clarification». International Communication Gazette (Netherlands: Kiuwer Academic Publishers) (41). P. 74.

12. Passeron J.-C. Theories of Social-Cultural Reproduction. International Social Science Journal. 1983. Vol. 38. № 4. P. 619-627.

13. Said E. Culture and Imperialism. London, Sage, 1994.

14. Said E. Power, Politics, and Culture: Interviews with Edward W. Said. New York, Publisher , 2001.

15. Tomlinson J. Cultural imperialism: a critical introduction. London : Continuum, 2002.

16. Weber M. The Rationalization of Education and Training. Gerth H., Mills C.W.R. From Max Weber: Essays in Sociology. New York, 1946. P. 240-244.

17. Willis P. Learning to Labor: How Working Class Kids Get Working-Class Jobs. New York, 1981. 